\section{NOTE ON THE SERUM REACTION OF MEDITERRANEAN FEVER AND ITS TREATMENT BY ANTITOXIC PLASMA.}

BY A. R. ALDRIDGE, M.B., C M. EdIN., D.P.H., SURGEON-CAPTAIN, ARMY MEDICAL STAFF.

THE cases were all examined by the microscopic method. Some of them were also tested in the sedimentation tubes recommended by Professor Wright, but the larger quantity of blood and longer time required for this method seemed to make the former preferable. The blood was collected in capillary tubes, which were sealed and allowed to stand for 24 hours. The tabe was then broken, the clot drawn out, and the serum transferred to a slide. In this way the serum obtained was not entirely free from blood corpuscles, but these did not appear to interfere in any way with the reaction. This serum was diluted with "loopfuls" of normal saline solution to the required amount, and a small quantity of a cultivation of the micrococcus Melitensis of Bruce mixed with it by means of a platinum loop. In all about 30 cases were examined, but, unfortunately, as the samples of blood were sent from various parts of the island of Malta, detailed notes were not kept of all.

TABLE I.-Cases of Fever which showed the Reaction.

\begin{tabular}{|c|c|c|c|c|}
\hline No. & $\begin{array}{l}\text { Day of } \\
\text { disease. }\end{array}$ & $\begin{array}{c}\text { Dilution } \\
\text { of } \\
\text { serum. }\end{array}$ & Reaction. & Remarks. \\
\hline 1 & 35th day. & $1-10$ & $\begin{array}{l}\text { Immediate ; no } \\
\text { reaction with } \\
\text { Eberth's bacillus. }\end{array}$ & $\begin{array}{l}\text { Died; ulceration of } \\
\text { large intestine. }\end{array}$ \\
\hline 2 & 26th day. & $\left\{\begin{array}{l}1-10 \\
1-25\end{array}\right\}$ & Inmediate. \{ & $\begin{array}{l}\text { Lasted } 9 \text { weeks ; anti- } \\
\text { toxin. }\end{array}$ \\
\hline 3 & $\left\{\begin{array}{l}\text { 3rd day. } \\
\text { 8th day. }\end{array}\right.$ & $\begin{array}{l}1-10 \\
1-10\end{array}$ & $\begin{array}{c}\text { None. } \\
\text { Immediate. }\end{array}$ & $\begin{array}{l}\text { Antitoxin on 9th day; } \\
\text { lasted } 11 \text { days. }\end{array}$ \\
\hline 4 & $\left\{\begin{array}{l}\text { 4th day. } \\
9 \text { th day. }\end{array}\right.$ & $\begin{array}{l}1-10 \\
1-10\end{array}$ & $\begin{array}{c}\text { None. } \\
\text { In half an hour. }\{\end{array}$ & $\begin{array}{l}\text { Antitoxin on 4th and } \\
\text { 14th days; lasted } 24 \\
\text { days. }\end{array}$ \\
\hline & 6th week. & $\left\{\begin{array}{c}1-10 \\
1-100\end{array}\right\}$ & $\begin{array}{c}\text { Immediate. } \\
\text { In half an hour. }\end{array}$ & $\begin{array}{l}\text { Very severe constitu- } \\
\text { tional symptoms ; } \\
\text { lasted over } 3 \text { months; } \\
\text { antit3xin. }\end{array}$ \\
\hline 6 & 16th day. & $1-10$ & Immediate. & $\begin{array}{l}\text { Severe ; with lung } \\
\text { complications; lasted } \\
\text { over } 4 \text { months; anti- } \\
\text { toxin. }\end{array}$ \\
\hline 7 & 10th week. & $1-10$ & Immediate. & $\begin{array}{l}\text { Prolonged; uncompli- } \\
\text { cated except with } \\
\text { "rheumatic" pains. }\end{array}$ \\
\hline 8 & 3rd week. & $1-10$ & $\begin{array}{l}\text { Immediate ; no } \\
\text { reaction with } \\
\text { Eberth's bacillus. }\end{array}$ & $\begin{array}{l}\text { Resembled entericfever } \\
\text { at first. }\end{array}$ \\
\hline 9 & 5th week. & $1-10$ & Immediate. & - \\
\hline 10 & 5th week. & $1-10$ & Immediate. & - \\
\hline$\pi$ & 9 th day. & $1-10$ & $\begin{array}{l}\text { Immediate ; no } \\
\text { reaction with } \\
\text { Eberth's bacillus. }\end{array}$ & $\begin{array}{l}\text { Resembled enteric fever } \\
\text { at first. }\end{array}$ \\
\hline 12 & 15th day. & $1-10$ & - & - \\
\hline 13 & 12th week. & $\left\{\begin{array}{l}1-10 \\
1-1 C 0\end{array}\right.$ & $\begin{array}{c}\text { Almost immediate. } \\
\text { None. }\end{array}$ & - \\
\hline 14 & 5th day. & $\left\{\begin{array}{l}1-10 \\
1-100 \\
1-500\end{array}\right.$ & $\begin{array}{l}\text { Immediate. } \\
\text { In half hour. } \\
\text { None. }\end{array}$ & - \\
\hline
\end{tabular}

TABLE II.-Cases of Slight Fever which did not show the Reaction.

\begin{tabular}{|c|c|c|c|c|}
\hline No. & $\begin{array}{l}\text { Day of } \\
\text { disease. }\end{array}$ & Dilution. & Reaction. & Remarks. \\
\hline 1\{ & $\begin{array}{l}\text { 4th } \\
13 \text { th }\end{array}$ & $\begin{array}{l}1-10 \\
1-10\end{array}$ & $\left.\begin{array}{l}\text { None. } \\
\text { None. }\end{array}\right\}$ & Fever lasted 9 days; no relapse. \\
\hline 2 & 4 th & $1-10$ & None. & Fever lasted 6 days; no relapse. \\
\hline 3 & 8th & $1-10$ & None. & Fever lasted 9 days; no relapse \\
\hline 4\{ & $\begin{array}{l}5 \text { th } \\
7 \text { th }\end{array}$ & $\begin{array}{l}1-10 \\
1-10\end{array}$ & $\left.\begin{array}{l}\text { None. } \\
\text { None. }\end{array}\right\}$ & Fever lasted 7 days; no relapse. \\
\hline
\end{tabular}

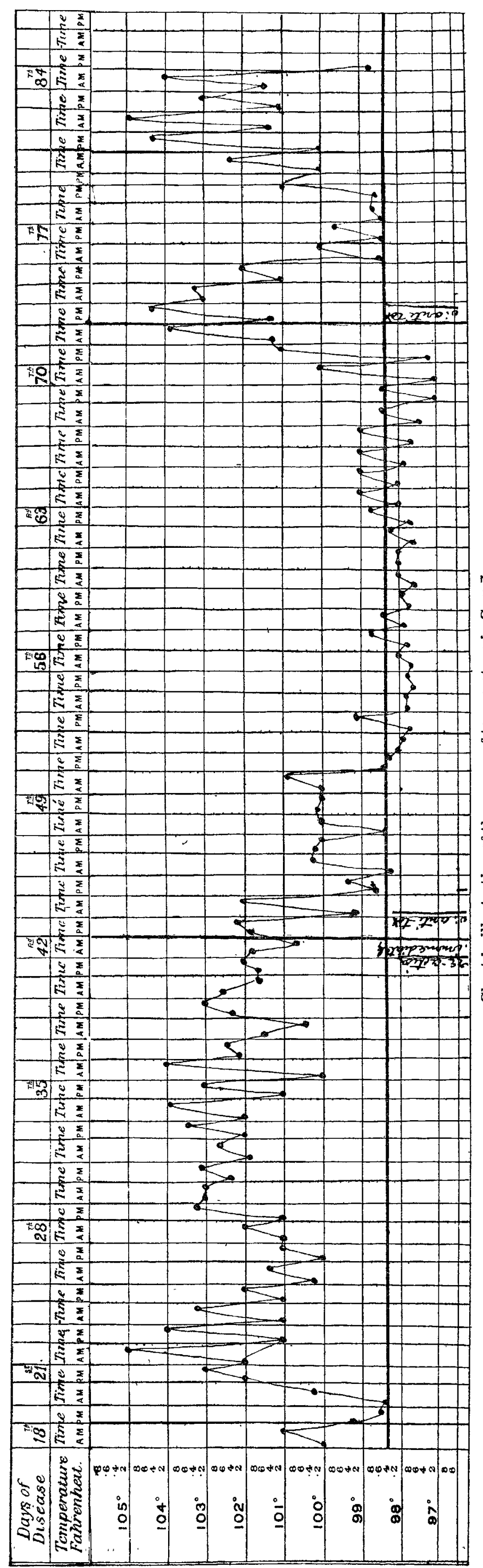


In every case which could be considered clinically typical of Mediterranean fever a reaction was obtained. There remained a certain number of cases of uncomplicated fever lasting from six to ten days, not at all uncommon in Malta, which did not give the reaction at any time during their course or after the fever had subsided. Four cases of enteric fever were also tested with negative results, but gave a reaction with the bacillus typhosus. The course of the disease confirmed these results and in two of them postmortem appearances also. Three cases during part of their eourse closely resembled enteric fever. Two of these were, in fact, so diagnosed at first, but no clumping was obtained with the bacillus typhosus, whereas the reaction with the micrococcus Melitensis was immediate, and in each case the after history left no doubt as to its nature; in two the nsual relapses and "rheumatic" pains recurred for several weeks, and in the third a necropsy confirmed the diagnosis.

As regards the date at which the reaction first appears the number of cases examined during the first week has been very few. The fifth day was the earliest on which it was obtained and in no case which ultimately showed the reaction was it found absent after this. The cases were at first all tested with a dilution of $1-10$ and the reaction in almost every case occurred immediately - that is, the micrococci were found clumped when the slide was put under the microscope, though a few could often be seen free; in from a quarter to half an hour these, too, were clumped. The reaction was also well marked in greater dilutions up to 1-100, though with such a rather longer time was generally required up to half an hour. If a considerable quantity of the micrococci be added in putting ap the specimen the clumping can be recognised with the naked eye.

Five cases were treated with the antitoxic plasma prepared by Professor Wright of Netley. Of these 2 cases which were in their sixth and ninth week of disease did not appear to be affected in any way by the injection. The third case was a very severe one with great prostration, in which the fever had lasted seven weeks with only one partial remission; 30 c.c. of the antitoxin were injected and a marked improvement commenced from the following day. The tongue, which had been dry and brown, and the breath, which had been very fcetid, improved very markedly; the collapse became less, and the temperature came down and remained normal from the eighth day after the injection (see Fig. 1). Another relapse occurred after three weeks and the temperature again decreased three days after another injection of $15 \mathrm{c} . \mathrm{c}$. of the antitoxin, but this improvement was not maintained and no more of the antitoxin was available.

The two other cases were recent ones and uncomplicated. In Case 430 c.c. of antitoxin were injected on the fifth day. The temperature, which had reached $106^{\circ}$, gradually fell till it ranged between normal and $101^{\circ}$; but on the fourteenth day, as it showed a tendency to rise again, another similar dose was given and was followed again by a fall of temperature,

FIt. 2.

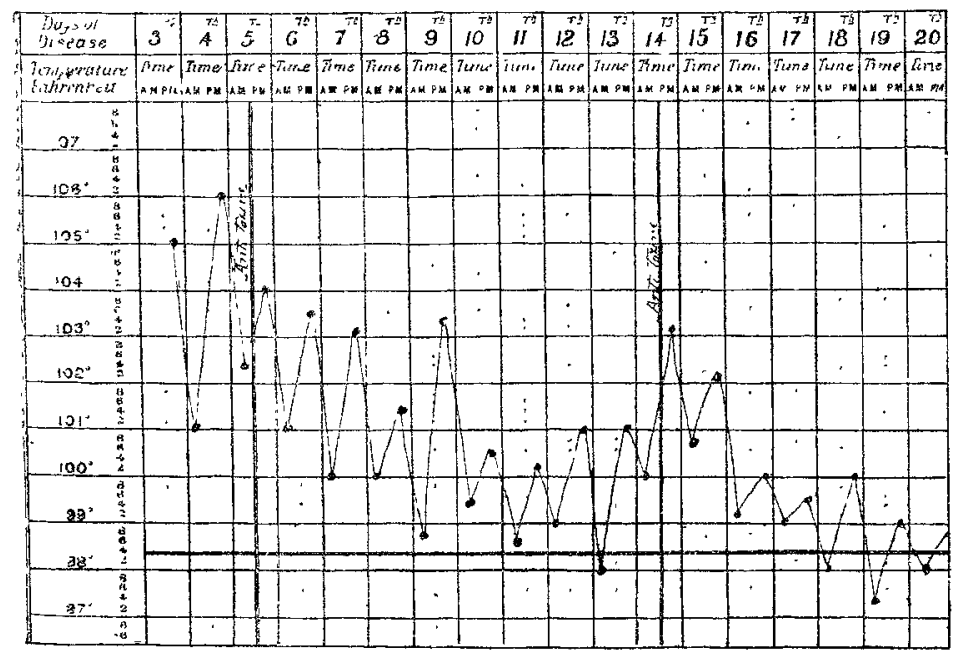

Chart in illustration of the course of temperature in Case 4.

After the twertieth day the temperature remained prac-

tically normal.

which did not rise above $100^{\circ}$ from the third day afterwards (see Fig. 2). This case did not show the serum reaction on the fourth day, but did so on the ninth, which, however, was after the first injection of antitoxin.
In Case 5 no serum reaction showed on the fourth day, but it did so on the eighth day. On the ninth day 30 c.c. of antitoxin were injected and the temperature, which had already shown a tendency to come down but continued between $100^{\circ}$ and $102^{\circ}$, reached and remained normal from the third day after the injection.

The recorded temperatures in Case 5 were as follows, two observations being taken each day, the first in the morning and the second in the evening:-Third day of the disease, $105.0^{\circ} \mathrm{F}$. and $101.0^{\circ}$; fourth, $103.0^{\circ}$ and $103.0^{\circ}$; fifth, $102.4^{\circ}$ and $103.0^{\circ}$; sixth, $101.4^{\circ}$ and $102.4^{\circ}$; seventh, $100.4^{\circ}$ and $102.2^{\circ}$; eighth, $100.2^{\circ}$ and $102.0^{\circ}$; ninth, $100.0^{\circ}$ and $102.6^{\circ}$ (antitoxin was injected); tenth, $100.0^{\circ}$ and $101.2^{\circ}$ eleventh, $100.4^{\circ}$ and $99.4^{\circ}$; twelfth, $98.4^{\circ}$ and $99.0^{\circ}$; thirteenth, $98.2^{\circ}$ and $99.0^{\circ}$; fourteenth, $98.0^{\circ}$ and $97.6^{\circ}$; fifteenth, $97.8^{\circ}$ and 98.4 ; and sixteenth, $97.6^{\circ}$ and $98.4^{\circ}$.

In coming to any conclusion as to the benefit resulting from the antitoxic serum a great difficulty lies in the fact that whereas from analogy with the use of similar serums in diphtheria and tetanus and also experimental inoculations the best results are to be expected in recent cases, yet diagnosis during the first week is very difficult, for besides enteric and other causes of fever there is a form of slight fever, already referred to, common in Malta. This lasts from about six to ten days and is apparently different from Mediterranean fever but only distinguishable from it by its short duration and by the serum test. Now this test does not seem to occur until the end of the first week and is itself of no value after the injection of antitoxin, which presumably will produce the reaction in the blood.

The cultivations used in these experiments were from Dr. T. Zammit's laboratory, with whose assistance much of the work was carried out.

Malta.

\section{Clinital allots:}

MEDICAL, SURGICAL, OBSTETRICAL, AND THERAPEUTICAL.

\section{A CASE OF DEPRESSED FRACTURE OH THE SKULL.}

By Clation A. Lane, M.D. Lond.

SURGEON-LIEUTENANT, INDIAY MEDICAL SERVICE.

ABout noon on Ang. 17th, 1897, while the 18th Bengal Lancers were encamped at Kushalgarh on their way to Kohat, a sowar was kicked on the head by his horse and was brought to the hospital tent. He was insensible, answering no questions. His pulse was irregular and very easily compressible; his pupils were neither contracted nor dilated and were equal. Crossing the centre of the left eyebrow and running upwards and inwards for an inch was wound leading down to the periosteum. Above and inside the upper end of this wound a depression conld be seen and felt through the skin and on putting a finger into the wound a fracture was felt starting near the middle of the upper edge of the orbit and curving upwards and finally outwards across the temporal ridge, where it was lost. The curve had a radius of about an inch and the portion of bone in its concavity was depressed, the greatest depression being along the line of fracture, where it amounted to $\frac{1}{3}$ in. The man's condition seemed to me to be so critical as not to justify my waiting to operate till water could be boiled and cooled, though the water I should have to use came from a dirty tank near the camp. Accordingly I began the operation at once, using carbolised water ( 1 in 40) for lotion and using the instruments provided in the field surgical pannier. On starting to enlarge the wound upwards the patient began to struggle, so the hospital assistant gave him chloroform. After trephining and inserting the elevator the depressed bone sprang at once into position and remained there. The bleeding vessels were twisted, not tied, and the skin was sewn up with silver wire without any drain. During the operation he stopped breathing, the pulse being still felt at the wrist, but after artificial respiration bad been continued for some minutes he began to breathe ayain. With the thermometer at over $100^{\circ} \mathrm{F}$. in the shade the cessation of artificial respiration was an even greater pleasure than usual. 20 minims of spirit of etber were injected after $\times 3$ 